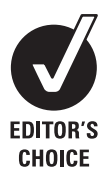

See Editorial Commentary, p 829

Washington University School of Medicine, Department of Neurology, St Louis, Missouri, USA

Correspondence to: Dr A Pestronk, Washington University School of Medicine, Department of Neurology, Box 8111, 660 South Euclid Ave, St Louis, MO 63110, USA; pestronka@neuro.wustl.edu

Received 24 August 2008 Revised 11 December 2008 Accepted 29 January 2009 Published Online First 23 February 2009

\title{
High aldolase with normal creatine kinase in serum predicts a myopathy with perimysial pathology
}

\author{
K Nozaki, A Pestronk
}

\section{ABSTRACT \\ Objective: To study the clinical and pathological correlations of neuromuscular patients with a high aldolase and normal creatine kinase (CK) in serum at presentation or during a symptomatic exacerbation.} Methods: Records and muscle biopsies were retrospectively reviewed in a consecutive series of 12 patients. Pathological results were compared to 75 abnormal muscle biopsies associated with acquired immune or inflammatory myopathy syndromes and 14 muscle biopsies from patients with myopathies associated with serum anti-Jo-1 antibodies.

Results: All patients with selectively elevated serum aldolase had muscle discomfort (92\%), weakness (proximal and distal) (50\%), or both. Frequent systemic features included joint pain $(75 \%)$, skin disorders $(75 \%)$ and pulmonary involvement (50\%). Electromyography patterns included normal $(36 \%)$, non-irritable myopathy (45\%) and irritable myopathy (18\%). Jo-1 antibodies were not found in the five patients tested. The distinctive feature of muscle biopsies was perimysial pathology $(92 \%)$, including acid phosphatase positive cellularity $(83 \%)$ and fragmented connective tissue $(75 \%)$.

Conclusions: Selectively elevated serum aldolase is associated with syndromes including myopathies with discomfort and weakness, systemic disorders and myopathology in perimysial connective tissue. The myopathy with perimysial pathology and the associated clinical syndromes seen in our patients are similar to disorders associated with antisynthetase antibodies. In patients with muscle discomfort or mild weakness and a normal CK, measurement of serum aldolase can be useful in the evaluation of possible myopathies.

Serum aldolase levels are commonly measured, and are elevated, in many types of myopathies, most often along with increased serum creatine kinase (CK). ${ }^{1}$ The clinical and pathological features of patients with high levels of serum aldolase in the setting of a normal CK are not well documented. The utility and associations of measurement of serum aldolase levels are not discussed in most textbooks dealing with muscle disorders. ${ }^{2}$ Individual case reports have described high serum aldolase with normal CK in patients with fasciitis ${ }^{3}$ and dermatomyositis-like syndromes. ${ }^{5}{ }^{6}$ In this study, we reviewed the clinical records and muscle pathology in 12 patients with high levels of serum aldolase but normal CK at presentation, or new exacerbation, of their neuromuscular symptoms.

\section{METHODS}

We reviewed the clinical features, laboratory records and myopathology of 12 patients identified from a search of Washington University
Neuromuscular records from October 1998 to March 2008 with elevated serum aldolase (>8.0 U/1) but normal serum CK $(\leqslant 170 \mathrm{U} / 1$ for females; $\leqslant 200 \mathrm{U} / 1$ for males) levels according to standards established in our hospital (BarnesJewish, St Louis, Missouri, USA) laboratory. Study procedures were approved by our institutional review board. Patients, who all had recent onset of neuromuscular complaints, included six men and six women, aged 5-60 years (mean 41 years). All were Caucasian except patient Nos 2 and 9 who were Black and Hispanic. High serum aldolase levels with normal CK were found at neuromuscular disease presentation in nine patients and during an exacerbation of neuromuscular symptoms in three (patient Nos 2, 5 and 7). One patient (No 7) had a high serum CK level 6 years before presentation that had returned to normal within 2 years. Panels of Jo-1 and other myositis specific serum antibodies were evaluated by clinical laboratories in Oklahoma or California. Electromyography (EMG) was performed in the neuromuscular electrodiagnostic laboratory in Washington University School of Medicine. Muscles biopsied were from the upper extremity, usually the deltoid, in seven patients and the lower extremity, usually the quadriceps, in five patients. All muscle biopsies were read by one of the authors (AP) without knowledge of the status of aldolase and CK levels. Cryostat sections of rapidly frozen muscle were processed in a standard fashion. ${ }^{78}$ Primary antibodies used in this study were CD4 (clone MT310), $\mathrm{C}_{5 b-9}$ components of complement (clone aE11; Dako, Carpenteria, California, USA), CD20 B-cell antigen (B-Ly1; ab25607; Abcam, Cambridge, Massachusetts, USA) and human major histocompatibility complex class I antigen (MHC-1; US Biological, Swampscott, Massachusetts, USA). Ulex lectin (L8146; Sigma, St Louis, Missouri, USA) was used to visualise capillaries. Biopsies were classified as having a reduced number of normal capillaries if more than three muscle fibres in a $20 \times$ field containing small muscle fibres had no adjacent Ulex stained capillaries. Regenerating muscle fibres were identified based on basophilia, enlarged large nuclei, coarse internal architecture on $\mathrm{NADH}$ and $2 \mathrm{C}$ type staining on ATPase stain at $\mathrm{pH}$ 4.3. Muscle pathology in our 12 patients with selectively high aldolase was compared with a separate series of 75 other abnormal muscle biopsies associated with acquired immune or inflammatory myopathy syndromes and 14 biopsies with myopathies associated with serum anti-Jo-1 antibodies. Fisher's exact tests were used to calculate the statistical significance of differences between 
Table 1 Clinical and laboratory features in patients with selectively high aldolase

\begin{tabular}{|c|c|c|c|c|c|c|c|c|c|c|c|c|c|}
\hline & $\begin{array}{l}\text { Patient } \\
\text { No } 1\end{array}$ & $\begin{array}{l}\text { Patient } \\
\text { No } 2\end{array}$ & $\begin{array}{l}\text { Patient } \\
\text { No } 3\end{array}$ & $\begin{array}{l}\text { Patient } \\
\text { No } 4\end{array}$ & $\begin{array}{l}\text { Patient } \\
\text { No } 5\end{array}$ & $\begin{array}{l}\text { Patient } \\
\text { No } 6\end{array}$ & $\begin{array}{l}\text { Patient } \\
\text { No } 7\end{array}$ & $\begin{array}{l}\text { Patient } \\
\text { No } 8\end{array}$ & $\begin{array}{l}\text { Patient } \\
\text { No } 9\end{array}$ & $\begin{array}{l}\text { Patient } \\
\text { No } 10\end{array}$ & $\begin{array}{l}\text { Patient } \\
\text { No } 11\end{array}$ & $\begin{array}{l}\text { Patient } \\
\text { No } 12\end{array}$ & $\%$ Patients \\
\hline Onset age (years)* & 38 & 31 & 37 & 60 & 32 & 55 & 46 & 59 & 5 & 55 & 18 & 52 & \\
\hline Sex (M:W) & $\mathrm{M}$ & $\mathrm{M}$ & W & $\mathrm{M}$ & W & W & W & W & W & $\mathrm{M}$ & M & $\mathrm{M}$ & \\
\hline \multicolumn{14}{|l|}{ Muscle } \\
\hline Weakness & 4 & 5 & 5 & 4 & 4 & 4 & 4 & 5 & 4 & 5 & 5 & 5 & 50 \\
\hline Distribution & $\mathrm{P}+\mathrm{D}$ & & & $\mathrm{P}+\mathrm{D}$ & $\mathrm{P}+\mathrm{D}$ & $\mathrm{P}$ & $\mathrm{P}+\mathrm{D}$ & & $\mathrm{P}+\mathrm{D}$ & & & & \\
\hline Discomfort & - & + & + & + & + & + & + & + & + & + & + & + & 92 \\
\hline Pulmonary & ILD & - & ILD & CPD & ILD & - & ILD & - & - & - & ILD & - & 58 \\
\hline Joint pain & - & + & + & + & + & + & + & - & + & + & + & - & 75 \\
\hline Skin disorder & Scl & WH & $\mathrm{R}$ & - & GVH & $\mathrm{R}$ & GVH & - & $\mathrm{R}$ & - & $\mathrm{MH}$ & $\mathrm{R}$ & 75 \\
\hline Raynaud's & - & - & - & - & - & - & + & - & - & - & - & - & 8 \\
\hline Aldolase & 10 & 21 & 14 & 13 & 13 & 13 & 11 & 12 & 13 & 13 & 9 & 11 & 100 \\
\hline Creatine Kinase & 71 & 99 & 170 & 25 & 26 & 26 & 27 & 77 & 143 & 25 & 101 & 58 & 0 \\
\hline ESR high & $\mathrm{n} / \mathrm{a}$ & - & + & + & + & $\mathrm{n} / \mathrm{a}$ & + & + & $\mathrm{n} / \mathrm{a}$ & - & - & - & 56 \\
\hline ANA+ & - & - & - & - & - & 1280 & 160 & - & $\mathrm{n} / \mathrm{a}$ & - & $\mathrm{n} / \mathrm{a}$ & - & 20 \\
\hline EMG & $M$ & $M$ & - & $\mathrm{M}$ & $\mathrm{IM}$ & $\mathrm{M}$ & $\mathrm{IM}$ & - & $\mathrm{M}$ & $\mathrm{n} / \mathrm{a}$ & - & - & 64 \\
\hline Systemic Dx & RDS & Eo & V & RA & GVH & Eo & GVH & MG & DM & Eo & SFPN & - & 92 \\
\hline Tx at evaluation & Aza & PLD & Aza & - & PLD & - & $\mathrm{M}, \mathrm{T}$ & - & - & - & - & - & \\
\hline Corticosteroid response & $\mathrm{n} / \mathrm{a}$ & $+\mathrm{P}$ & $+\mathrm{MP}$ & $+\mathrm{P}$ & $+\mathrm{MP}$ & $+\mathrm{P}$ & $+\mathrm{MP}$ & $\mathrm{n} / \mathrm{a}$ & $+\mathrm{P}$ & $+\mathrm{P}$ & $+P$ & $\mathrm{n} / \mathrm{a}$ & 100 \\
\hline
\end{tabular}

*Mean age was 41 years.

Weakness: strength of weakest muscles (MHC scale); $\mathrm{P}$, proximal; $\mathrm{D}$, distal.

Pulmonary: dyspnoea, cough or fibrosis; CPD, chronic obstructive pulmonary disease; ILD, interstitial lung disease.

Skin disorder: Scl, scleroderma; WH, poor wound healing; R, rash; GVH, graft vs host disease; MH, Mechanic's hands.

Raynaud's, Raynaud's phenomenon.

Aldolase (U/l; highest level, normal $\leqslant 8$ ).

ESR high, erythrocyte sedimentation rate $>20 ;-$, negative/absent; $n / a$, not available.

$\mathrm{ANA}+$, antinuclear antibody titre $>1: 80$.

EMG, electromyography; M, myopathy; IM, irritable myopathy; -, normal.

Systemic Dx, systemic diagnosis; RDS, respiratory distress syndrome; Eo, eosinophilia; V, vasculitis; RA, rheumatoid arthritis; MG, myasthenia gravis; DM, dermatomyositis; SFPN, small fibre polyneuropathy of unknown aetiology.

Tx at evaluation, treatment at time of evaluation, testing and biopsy; Aza, azathioprine; PLD, prednisone low dose (10 mg/day); P, prednisone (50-100 mg/day at onset); $\mathrm{M}$, mycophenolate; T, tacrolimus.

Corticosteroid response: marked reduction in pain or increased strength after treatment with indicated medication. MP, methylprednisolone intravenously (1 $\mathrm{g} /$ day for 5 days).

groups. To correct for multiple comparisons, only differences with $p<0.01$ were considered significant.

\section{RESULTS}

Our patients with elevated serum aldolase but normal creatine kinase generally had multisystem disorders (table 1).
The most common neuromuscular feature was muscle discomfort $(92 \%)$, including myalgias or cramps. Half of our patients had weakness, usually of mild to moderate severity. Weakness, when present, was most often symmetric and diffuse and involved both proximal and distal musculature of the arms and legs. Joint discomfort (75\%) and skin disorders (75\%) were

Table 2 Muscle pathology in patients with selectively high aldolase

\begin{tabular}{|c|c|c|c|c|c|c|c|c|c|c|c|c|c|}
\hline & $\begin{array}{c}\text { Patient } \\
\text { No } 1\end{array}$ & $\begin{array}{c}\text { Patient } \\
\text { No } 2\end{array}$ & $\begin{array}{c}\text { Patient } \\
\text { No } 3\end{array}$ & $\begin{array}{c}\text { Patient } \\
\text { No } 4\end{array}$ & $\begin{array}{c}\text { Patient } \\
\text { No } 5\end{array}$ & $\begin{array}{c}\text { Patient } \\
\text { No } 6\end{array}$ & $\begin{array}{c}\text { Patient } \\
\text { No } 7\end{array}$ & $\begin{array}{c}\text { Patient } \\
\text { No } 8\end{array}$ & $\begin{array}{c}\text { Patient } \\
\text { No } 9\end{array}$ & $\begin{array}{c}\text { Patient } \\
\text { No } 10\end{array}$ & $\begin{array}{c}\text { Patient } \\
\text { No } 11\end{array}$ & $\begin{array}{c}\text { Patient } \\
\text { No } 12\end{array}$ & $\%+$ ve \\
\hline Perimysial pathology & & & & & & & & & & & & & 92 \\
\hline Fragmentation & + & + & + & - & + & + & + & + & + & + & - & - & 75 \\
\hline Acid phosphatase + cells & + & + & + & + & + & + & + & - & + & + & - & + & 83 \\
\hline Alkaline phosphatase stain & + & + & + & + & - & + & + & - & + & - & - & - & 58 \\
\hline \multicolumn{14}{|l|}{ Inflammation } \\
\hline Mononuclear cell foci & & & & & & & & & & & & & 50 \\
\hline Endomysial & - & - & - & + & - & + & - & - & + & - & - & - & 25 \\
\hline Perivascular & + & - & + & - & - & - & - & - & - & - & - & + & 25 \\
\hline \multicolumn{14}{|l|}{ Muscle fibre pathology } \\
\hline Perifascicular & & & & & & & & & & & & & 58 \\
\hline Atrophy & + & - & - & + & + & + & - & - & + & + & - & + & 58 \\
\hline Necrosis and regeneration & + & - & - & - & - & + & - & - & + & + & - & - & 33 \\
\hline COX stain reduced & - & - & - & - & - & + & - & - & + & - & - & - & 17 \\
\hline MHC-I staining & + & - & + & + & + & + & + & + & + & + & - & + & 83 \\
\hline Small vessel pathology & & & & & & & & & & & & & 17 \\
\hline Alkaline phosphatase stain & - & - & - & - & - & - & - & - & - & - & - & - & 0 \\
\hline C5b-9 deposition & - & - & - & - & + & - & + & - & - & - & - & - & 17 \\
\hline Capillary number reduced & - & - & - & - & - & - & - & - & + & - & - & - & 8 \\
\hline
\end{tabular}

Muscle pathology findings: + , present; - , negative/absent; $\%+v e$, per cent positive.

Alkaline phosphatase stain $=$ increased number of endomysial capillaries with positive staining.

COX, cytochrome oxidase; MHC-I, major histocompatibility complex. 
the most frequent systemic features. Skin involvement included rashes similar to dermatomyositis, graft-versus-host reactions, Mechanic's hands and poor wound healing. Pulmonary involvement was manifest by symptoms of dyspnoea and cough and imaging studies that revealed lung fibrosis. Most patients had additional systemic immune disorders. These included eosinophilia, graft-versus-host disease, myasthenia gravis, childhood dermatomyositis, rheumatoid arthritis and vasculitis. None of our patients had an associated neoplasm identified during the period they were followed in our clinic. All patients who received corticosteroid treatment showed sustained improvement, usually with resolution of their muscle discomfort or weakness.

Aldolase levels varied from 9 to $21 \mathrm{U} / 1$ (table 1). Serum CK was usually well below the upper limit of normal. Jo-1 antibodies were not present in the five patients who were tested. EMG was normal in four patients. Others had myopathic changes with or without spontaneous activity. The muscle biopsy was abnormal in $92 \%$ of patients (table 2). All abnormal biopsies had perimysial pathology, typically acid phosphatase positive cellularity and fragmentation of the connective tissue (fig 1). Alkaline phosphatase staining of the perimysium (fig 1) was found in $58 \%$. Small foci of CD4 positive mononuclear cells around intermediate sized perimysial vessels, or in the endomysium among muscle fibres, were observed in $50 \%$. The most common muscle fibre pathology (83\%) was MHC class I upregulation by morphologically normal fibres. Routine muscle histochemistry showed evidence of muscle fibre pathology in $58 \%$ of patients. Muscle fibre pathology was most commonly atrophy of perifascicular muscle fibres, with necrosis and regeneration in these regions in some cases. Two patients had reduced cytochrome oxidase but normal succinate dehydrogenase staining in muscle fibres in regions of perifascicular atrophy. Capillary pathology was uncommon.

Perimysial connective tissue fragmentation and acid phosphatase positive cellularity were the only two features that occurred more frequently in aldolase positive patients compared with the acquired immune myopathy control biopsies (table 3 ). There were no histochemical differences comparing aldolase positive patients to Jo-1 antibody positive control biopsies.

\section{DISCUSSION}

During evaluations of patients for the presence and type of myopathy, testing typically includes electrodiagnostic evaluation of muscle and measurement of levels of serum CK. Our results showed that measurement of serum aldolase can provide additional information about specific clinical and pathological myopathy syndromes and sensitivity regarding the presence of an immune myopathy.

Clinically, selectively elevated levels of serum aldolase with normal CK in our patients were associated with an acquired multisystem syndrome that included a myopathy with perimysial pathology (MPP). Common neuromuscular features were discomfort, including myalgias and cramps, and weakness. Systemic features included skin, pulmonary and joint disorders. The multisystem clinical syndrome in some of our patients is similar to the MPP associated with Jo-1 antibodies, ${ }^{8}{ }^{9}$ but Jo-1 and antisynthetase antibodies were absent in the five patients who were tested. Several of our patients had clinical syndromes and pathology that could be classified as dermatomyositis and are similar to a previously described dermatomyositis patient
Figure 1 Perimysial pathology in patients with selectively elevated aldolase. (A) Fragmentation and cellularity of the perimysium with no muscle fibre pathology. (B) Fragmentation and cellularity of the perimysium with perifascicular muscle fibre pathology, including atrophy and some basophilia of cytoplasm. (C) Acid phosphatase positive staining of most cells in the perimysium. (D) Abnormal alkaline phosphatase staining of the perimysium. Bar $=35 \mu \mathrm{M}$.
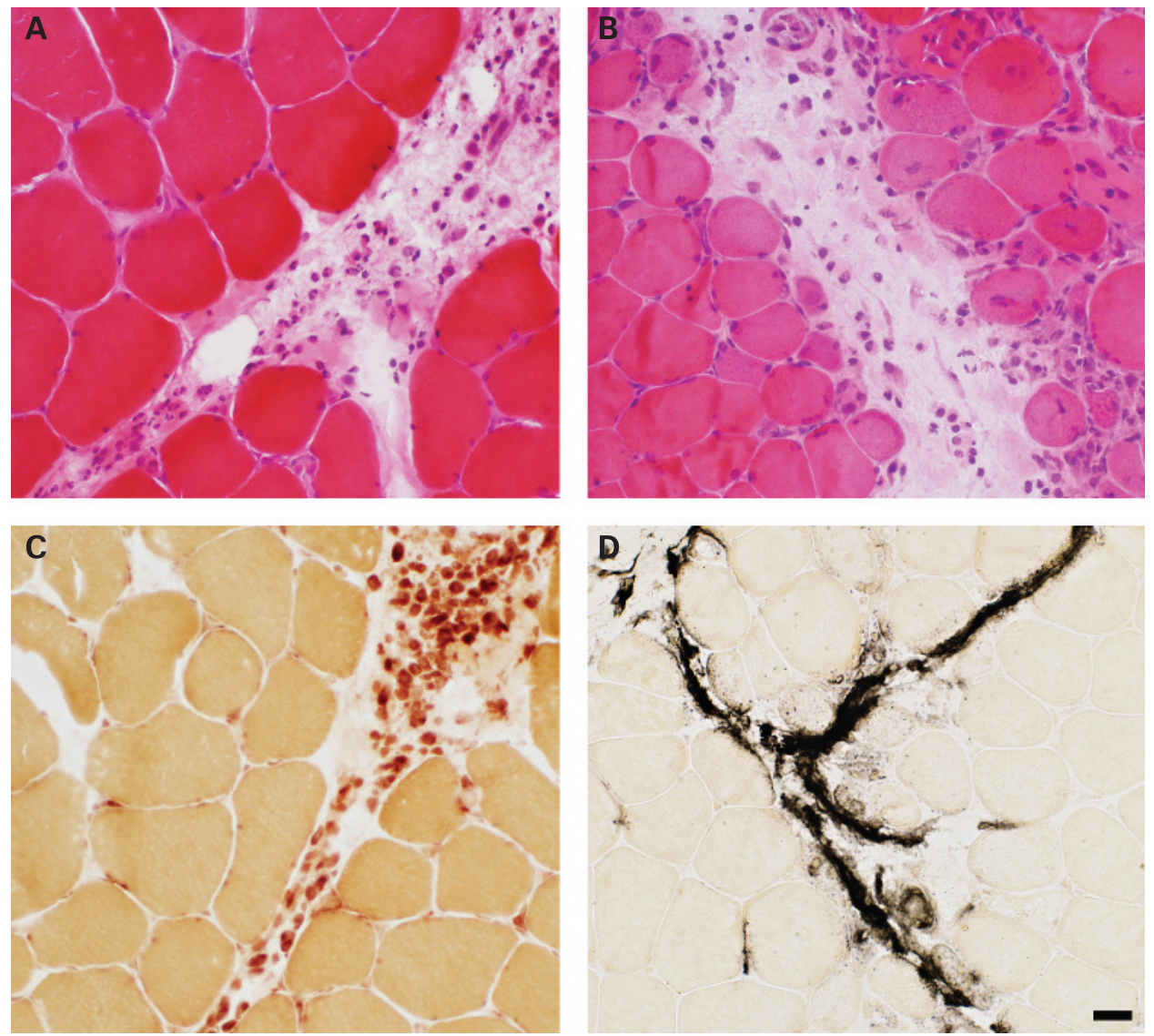
Table 3 Muscle pathology in myopathies with selectively high serum aldolase: comparative features

\begin{tabular}{|c|c|c|c|c|c|c|c|c|}
\hline & \multicolumn{2}{|c|}{$\begin{array}{l}\text { IIM group } \\
\text { (75 biopsies) }\end{array}$} & \multicolumn{2}{|c|}{$\begin{array}{c}\text { Aldolase }+ \\
\text { group } \\
\text { (12 biopsies) }\end{array}$} & \multirow{2}{*}{$\begin{array}{l}\text { p Value } \\
\text { (IIM vs } \\
\text { Ald +) }\end{array}$} & \multicolumn{2}{|c|}{$\begin{array}{c}\text { Jo-1 group } \\
\text { (14 biopsies) }\end{array}$} & \multirow{2}{*}{$\begin{array}{l}\text { p Value } \\
\text { (Jo-1 vs } \\
\text { Ald }+ \text { ) }\end{array}$} \\
\hline & No +ve & $\%+v e$ & No +ve & $\%+\mathbf{v e}$ & & No +ve & $\%+$ ve & \\
\hline \multicolumn{9}{|l|}{ Inflammation, cell foci } \\
\hline Perimysial & 19 & 25 & 0 & 0 & 0.06 & 1 & 7 & 1.0 \\
\hline Endomysial & 45 & 60 & 3 & 25 & 0.03 & 2 & 14 & 1.0 \\
\hline Perivascular, med size vessel & 29 & 39 & 2 & 17 & 0.20 & 2 & 14 & 1.0 \\
\hline \multicolumn{9}{|l|}{ Muscle fibre features } \\
\hline Enlarged muscle fibres & 20 & 27 & 0 & 0 & 0.06 & 0 & 0 & 1.0 \\
\hline \multicolumn{9}{|l|}{ Perifascicular } \\
\hline Atrophy & 20 & 27 & 7 & 58 & 0.04 & 12 & 86 & 0.20 \\
\hline Necrosis and regeneration & 10 & 13 & 4 & 33 & 0.09 & 7 & 50 & 0.45 \\
\hline COX stain reduced & 7 & 9 & 2 & 17 & 0.60 & 1 & 7 & 1.0 \\
\hline Regional necrosis & 4 & 5 & 0 & 0 & 1.0 & 0 & 0 & 1.0 \\
\hline MHC I on muscle fibre surface & 64 & 85 & 10 & 83 & 1.0 & 13 & 93 & 0.58 \\
\hline \multicolumn{9}{|l|}{ Perimysium } \\
\hline Fragmentation & 17 & 23 & 9 & 75 & $<0.001$ & 13 & 93 & 0.31 \\
\hline Alkaline phosphatase+ & 30 & 40 & 7 & 58 & 0.35 & 12 & 86 & 0.19 \\
\hline AcP+cells & 21 & 28 & 10 & 83 & $<0.001$ & 12 & 86 & 1.0 \\
\hline \multicolumn{9}{|l|}{ Endomysium } \\
\hline Increased connective tissue & 13 & 17 & 0 & 0 & 0.20 & 1 & 7 & 1.0 \\
\hline $\mathrm{C}_{5 \mathrm{~b}-9}$ deposition, diffuse & 15 & 20 & 0 & 0 & 0.12 & 2 & 7 & 0.48 \\
\hline \multicolumn{9}{|l|}{ Capillaries } \\
\hline Reduced number & 11 & 15 & 1 & 8 & 1.0 & 0 & 7 & 1.0 \\
\hline Enlarged size & 14 & 19 & 0 & 0 & 0.20 & 1 & 7 & 1.0 \\
\hline Alkaline phosphatase stain & 11 & 15 & 0 & 0 & 0.35 & 1 & 7 & 1.0 \\
\hline C5b-9 deposition & 18 & 24 & 2 & 17 & 0.73 & 1 & 7 & 1.0 \\
\hline
\end{tabular}

with high aldolase and normal CK. ${ }^{5}$ Weakness and muscle discomfort improved after treatment with corticosteroids.

The distinctive myopathological feature (tables 2 and 3, fig 1) found in most of our patients was prominent perimysial connective tissue pathology. The prominent involvement of connective tissue with damage to, and acid phosphatase positive cellularity in, the perimysium, without involvement of capillaries, was similar to the MPP found in anti-Jo-1 myopathy syndromes (table 3). ${ }^{8}$ Selective perimysial pathology has also been reported in other syndromes involving connective tissue such as fasciitis ${ }^{2}$ and perimyositis, ${ }^{10}$ especially syndromes associated with eosinophilia. Eosinophilia was present in $25 \%$ of our patients. Serum aldolase levels have only rarely been reported in these syndromes.

The frequent MHC class I upregulation by muscle fibres in our patients is similar to that found in other immune and inflammatory myopathies (table 3). Despite the common involvement of skin and the perifascicular myopathy in our patients, evidence of a microvasculopathy, a common feature in dermatomyositis, ${ }^{11}{ }^{12}$ was only occasionally present. Capillary pathology, such as deposition of $\mathrm{C}_{5 \mathrm{~b}-9}$ components of complement, enlargement in size or reduction in number, was only present in $25 \%$. The perifascicular muscle fibre changes could be related to proximity to the perimysial pathology.

Aldolase activity is present in many tissues. ${ }^{1}$ The specific tissue sources of the elevated aldolase in the serum of our patients remains to be determined. Aldolase levels in serum may be increased in liver disease, metastatic neoplasms and anaemias. The pathological involvement of perimysium suggests that similar connective tissue antigens in muscle, lung, joints and skin could underlie the multisystem nature of the syndrome found in our aldolase positive patients. The relatively low CK in our patients is most likely related to the absence, or low levels, of muscle fibre necrosis in our patients. There was no evidence of disorders that can suppress CK levels such as hypothyroidism, Cushing's syndrome, multiorgan failure or severe muscle wasting ${ }^{13}{ }^{14}$ in any of our patients.

It is notable that four of our patients, $36 \%$ of those tested, had normal EMG. It is common practice that, in the setting of normal strength, EMG and serum CK, muscle biopsy is not performed because of presumed low yield of the procedure. ${ }^{15}$ Our series suggests that, with symptoms of myalgias or cramps, aldolase can be a useful test in the setting of an otherwise negative neuromuscular evaluation. A selectively high serum aldolase, especially with associated clinical involvement of systems such as skin, joints or lungs, suggests that a muscle biopsy may provide useful information. Such patients often have an MPP syndrome that is responsive to corticosteroid treatment.

Acknowledgements: We thank Rati Choksi and Jim Planer for technical assistance. Funding: This study was financed by the Washington University Neuromuscular Research Fund.

Competing interests: None.

Ethics approval: The study was approved by the Washington University, St Louis, Human Research Protection Office (HRPO). 


\section{REFERENCES}

1. Lott JA, Landesman PW. The enzymology of skeletal muscle disorders. Crit Rev Clin Lab Sci 1984;20:153-90.

2. Engel AG, Franzini-Armstrong C. Myology: basic and clinical. New York: McGrawHill, 2004.

3. Fujimoto $\mathbf{M}$, Sato $\mathrm{S}$, Ihn $\mathrm{H}$, et al. Serum aldolase level is a useful indicator of disease activity in eosinophilic fasciitis. J Rheumatol 1995;22:563-5.

4. Quintero-Del-Rio Al, Punaro M, Pascual V. Faces of eosinophilic fasciitis in childhood. J Clin Rheumatol 2002:8:99-103.

5. Carter JD, Kanik KS, Vasey FB, et al. Dermatomyositis with normal creatine kinase and elevated aldolase levels. J Rheumatol 2001;28:2366-7.

6. Sato S, Hirakata M, Kuwana M, et al. Autoantibodies to a 140-kd polypeptide, CADM-140, in Japanese patients with clinically amyopathic dermatomyositis. Arthritis Rheum 2005:52:1571-6

7. Miller T, Al Lozi MT, Lopate G, et al. Myopathy with antibodies to the signal recognition particle: clinical and pathological features. J Neurol Neurosurg Psychiatry 2002;73:420-8.
8. Mozaffar T, Pestronk A. Myopathy with anti-Jo-1 antibodies: pathology in perimysium and neighbouring muscle fibres. J Neurol Neurosurg Psychiatry 2000;68:472-8.

9. Schmidt WA, Wetzel W, Friedlander R, et al. Clinical and serological aspects of patients with anti-Jo-1 antibodies: an evolving spectrum of disease manifestations Clin Rheumatol 2000;19:371-7.

10. Zivkovic SA, Lacomis D, Clemens PR. Chronic eosinophilic perimyositis with persistent myalgias. Muscle Nerve 2002;25:461-5.

11. Emslie-Smith AM, Engel AG. Microvascular changes in early and advanced dermatomyositis: a quantitative study. Ann Neurol 1990;27:343-56.

12. Kissel JT, Mendell JR, Rammohan KW. Microvascular deposition of complement membrane attack complex in dermatomyositis. N Engl J Med 1986;314:329-34.

13. Pestronk A. Creatine kinase. Neuromuscular Disease Center 2009 World Wide Web URL: http://neuromuscular.wustl.edu/lab/cknomyo.html\#cklow laccessed 6 May 2009).

14. Rosalki SB. Low serum creatine kinase activity. Clin Chem 1998;44:905

15. Lacomis D. The utility of muscle biopsy. Curr Neurol Neurosci Rep 2004:4:81-6.

\section{Neurological picture}

\section{Reversible posterior leukoencephalopathy syndrome caused by hanging}

\section{CASE REPORT}

A 29-year-old man was referred after attempting suicide by hanging himself. On admission, blood pressure was 127/ $71 \mathrm{~mm} \mathrm{Hg}$, heart rate 168/min and the patient had a score of 11 on the Glasgow Coma Scale. Pupils were normal in size and equal, and reacted to light promptly. Neurological examination revealed no motor weakness or sensory disturbance. The patient was intubated because of the risk of an obstructed airway. Head CT on admission was normal. On day 4, the patient became alert and was extubated. On day 7 , the patient complained of binasal inferior quadrant hemianopsia. On day 9, head CT showed low density areas in the white matter in the bilateral occipital lobes, with partial haemorrhagic change (fig 1A). MR imaging demonstrated hyperintensity on T2 weighted images in the white matter in the bilateral occipital lobes (fig 1B). Although diffusion weighted imaging revealed no signal change except for a haemorrhagic lesion, apparent diffusion coefficient maps were increased in the bilateral occipital lobes (fig 1C, D). $M R$ angiography of the head and neck and MR venography of the head were normal. He was treated conservatively for 11 days and discharged to another hospital. Follow-up MR imaging, on day 25, revealed remarkable resolution of the abnormal signals except for the haemorrhagic lesion (fig 1E, F).

\section{DISCUSSION}

Although hanging is one of the most common methods of suicide, there have been only a few reports on head CT or MR imaging in hanging. ${ }^{1-8}$ The reported CT abnormalities in hanging include round bilateral low density areas in the globi pallidi, ${ }^{1}$ diffuse swelling and symmetrical low density areas in the basal ganglia or thalamus, ${ }^{3}{ }^{4}$ and subcortical haematomas with a subarachnoid haemorrhage. ${ }^{24}$ The reported MR imaging abnormalities in hanging include symmetrical hyperintensity on T2 weighted images in the bilateral basal ganglia, thalamus or midbrain. ${ }^{4-6}$ Furthermore, Ikenaga et $a l^{7}$ reported a case of multiple infarctions due to dissection of the carotid artery caused by hanging. The reported main causes of brain damage in hanging include hypoxia causing cerebral infarction, ${ }^{2}$ venous hypertension ${ }^{4}$ and dural sinus thrombosis. ${ }^{8}$

Reversible posterior leukoencephalopathy syndrome (RPLS) is characterised by visual disturbance, seizures, headache and altered mental status associated with white matter changes, particularly in the occipital lobes, which usually completely reverses. ${ }^{9}{ }^{10} \mathrm{MR}$ imaging in our case demonstrated reversible abnormal signals in the white matter in the bilateral occipital lobes, which was compatible with a diagnosis of RPLS. Although hypertensive encephalopathy is the most common cause of RPLS, recently it has been increasingly recognised in association with several other conditions, such as chemotherapy, transplantation, transfusion and renal failure. ${ }^{9}$ Although the mechanism of RPLS is not yet understood, two theories have historically been proposed: (1) severe hypertension leads to failed autoregulation and subsequent hyperperfusion, and (2) vasoconstriction and hypoperfusion. ${ }^{10}$ In our case, transient hypertension during hanging might have caused RPLS. Alternatively, hypoperfusion due to hanging might have led to breakage of the blood-brain barrier.

To our knowledge, a case of RPLS caused by hanging has never been reported in the literature. RPLS should be considered as a differential diagnosis of brain lesion after hanging. 